Araştırma Makalesi/Research Article

\title{
Trakya'da Bazı Kışılık Tek Yıllık Tarla Bitkilerinin Silaj Üretiminde Kullanılma İmkânlarının Araştırılması
}

\author{
Mehmet Erdem Karaevli $^{1 *}$ Harun Baytekin $^{1}$ \\ ${ }^{1}$ ÇOMÜ Ziraat Fakültesi, Tarla Bitkileri Bölümü. 17100/Çanakkale \\ *Sorumlu yazar: karaevlierdem_1@hotmail.com
}

Geliş Tarihi: 12.07.2018

Kabul Tarihi: 06.12.2018

\section{Öz}

$\mathrm{Bu}$ araştırma, hayvansal üretimin yoğun olarak yapıldı̆̆ 1 Trakya Bölgesi’nde, sulanamayan kıraç arazilerde silaj üretimi için, buğday, arpa, tritikale, yulaf ve kolza gibi bazı kışlık tarla bitkilerinin silaj üretim potansiyellerinin belirlenmesi amacıyla yürütülmüştür. Çalışmada Tekirdağ ilinin Kayı köyünde üretici arazilerinde hasat edilen buğday, arpa, yulaf, tritikale ve kolza hasıllarına farklı miktar ve dozlarda arpa kırması ve inokulant eklenmiş ve bitki türlerinin silaj özellikleri gözlenmiştir. Araştırmada en yüksek yeşil ot ve kuru madde verimleri kolza ve buğdaydan elde edilmiştir. Silaj yapımında kullanılan arpa kırması ve inokulant düzeyi arttıkça silaj özelliklerinde olumlu gelişmeler kaydedilmiştir.

Anahtar Kelimeler: Silaj, Kışlık tahıllar, İnokulant, Arpa Kırması

\section{Investigation of the Possibilities of Using Some Winter Annual Field Crops in Silage Production in Trakya Region}

Abstract

This research has been conducted in order to determine silage production potentials of some winter annual field crops, such as wheat, barley, triticale, oat and canola, for silage production in unirrigated zone of Trakya Region where animal production is intensively carried out. Barley cracks and inoculants were added to green fodder of wheat, barley, oats, triticale and canola harvested in the land of producers in Kay1 village of Tekirdağ province, and silage characteristics of plant species were also observed during the study. According to the result of this study, the highest yields of fresh hay and dry matter have been obtained from canola and wheat. On the other hand, as barley cracks and inoculant level used during silage preparation increased favorable changes in silage characteristics were recorded.

Keywords:Silage, winter cereal crops, inoculant, barley crack

\section{Giriş}

Ülkemizde tarım arazilerinin genel olarak engebeli oluşu ve kuru tarıma yatkın oluşundan dolayı mısır, yonca, sorgum, sorgum sudan otu melezi gibi sulu tarıma dayalı olarak yetiştirilebilen silajlık yem bitkilerinin yetiştiricilik alanları oldukça kısıtlıdır. Buğday, arpa, yulaf, çavdar, tritikale gibi serin iklim tahılları ile kolza kuru tarım arazilerinde yaygın olarak yetiştirilmektedir. Bu nedenle, kıraç ve engebeli arazilerde serin iklim tahıllarından silaj üretimi amacıyla yararlanmak önem arz etmektedir. Yetiştiriciliğinin kolay ve daha ekonomik olmasından dolayı buğday, arpa ve yulafin tarımı üreticiler tarafindan daha çok tercih edilmektedir. Bundan dolayı bu ürünlerden silaj yapılması ve hayvan beslemede kullanılması, artan kaba yem açığının kapatılmasında önemli görünmektedir.

Yeşil ve su bakımından zengin yemlerin havasız ortamda fermantasyona uğratılarak (ekşitilerek) saklanmasına silolama, bu işlem sonucu elde edilen yeme de silo yemi veya silaj denmektedir. Ülkemizde mera alanlarının kısıtlı, otlatma mevsiminin sınırlı oluşu ve kış aylarında hayvanların kaba yem ihtiyacı önemli bir problem olmasından dolayı silaj yapımı önem arz etmektedir. Kışın hayvanlar için gerekli olan kaba yemler yeşil ve sulu yemlerden sağlanırsa hayvanların verimleri yıl boyu korunabilmektedir. Silajı yapılacak ürünün kimyasal ve mikrobiyolojik yapısı, hasat, soldurma, parçalama, sıkıştırma gibi etkenler silaj niteliği üzerinde etkili olmaktadır. Silaj yapımı birbiri ile ilişkili üç etkenin etkisi altında gerçekleşmektedir. Bunlar silaj materyali, silaj amenajmanı ve fermantasyonudur. Söz konusu fermantasyon aerobik ve anaerobik olmak üzere çok faklı mikroorganizmaların etkinliği altında gerçekleşmektedir.

$\mathrm{Bu}$ çalışmanın amac1; hayvansal üretimin yoğun olarak yapıldığ 1 Trakya Bölgesi'nde, sulanamayan kıraç arazilerde silaj üretimi için, buğday, arpa, tritikale, yulaf, kolza gibi bazı kışlık tarla bitkilerinin silaj üretim potansiyellerinin araştırılmasıdır. 


\section{Materyal ve Yöntem}

Tarla denemeleri Tekirdağ merkeze bağlı Kayı mahallesinde 2013-2014 yetiştirme sezonunda, laboratuar çalışmaları ise Çanakkale Onsekiz Mart Üniversitesi Ziraat Fakültesi Tarla Bitkileri Bölümünde yürütülmüştür. Denemede, bölgede en fazla ekimi ve üretimi yapılan buğday çeşidi Enola, iki sıralı arpa çeşidi Sladoran, tritikale çeşidi Turan 2000, kolza çeşidi Pioneer Pt 200 ve yerel yulaf genotipleri kullanılmışıtır.

Araştırma alanı toprakları genelde killi tınlı bünyeye sahip olup, pH'sı 6,39 civarındadır. Kireççe fakir olan arazide, 75,68 kg/da potasyum, 14,77 kg/da fosfor bulunmaktadır. Organik madde içeriği \% 2,24 düzeyindedir.

Araştırma bölünmüş parseller deneme desenine göre 3 tekrarlamalı olarak yürütülmüştür. Ana parselleri bitki türleri, alt parselleri ise silaj katkı maddeleri oluşturmuştur. Silaj katkı maddeleri olarak arpa kırması ve laktik asit bakterisi içeren bakteri solüsyonu kullanılmıştır. Arpa kırması, biçilip parçalanmış materyale \%2,5, 5,0 ve 7,5 oranlarında ilave edilmiş̧ir. Bakteri solüsyonu ise, $1 \mathrm{~g} /$ ton, 2 $\mathrm{g} /$ ton, $3 \mathrm{~g} /$ ton dozlarında hazırlanarak biçilmiş materyalin torbalara doldurulması esnasında eklenmiştir. Silaj materyalleri $25 \mathrm{~kg}$ 'lık torbalara 3 tekrarlamalı olarak doldurulmuş ve 6 hafta süreyle olgunlaşması beklenmiştir. Torbalar 6 hafta sonra açılarak silaj kalite özellikleri Alman DLG örgütünün kriterlerine göre duyusal analizlere dayalı olarak belirlenmiştir.

Mısır ve sorguma göre karbonhidratça biraz daha fakir olan serin iklim tahılları ve kolza yeşil materyalinin farklı katkı maddeleriyle silaj kalitesinin artırılmasına çalışılmıştır. Çalışmada kolza silajları bozulduğundan, kolzayla ilgili silaj gözlemleri alınmamıştır.

Araştırmada, bitki boyu, yeşil ot verimi, kuru madde verimi tarla koşullarında klasik yöntemlere göre tespit edilmiş, silaj örneklerinde ise renk, koku ve strüktür duyusal testlerle, ham protein ve ham selüloz oranları ise NIR cihazı kullanılarak belirlenmiştir.

Araştırmada elde edilen veriler, bölünmüş parseller deneme desenine göre varyans analizine tabi tutulmuş, ortalamalar arasında fark ise LSD (\%5)'e göre bulunmuştur.

\section{Bulgular ve Tartışma \\ Tarla Çalışmaları}

Bitki boyu, yeşil ot ve kuru madde verimlerine ait ortalamalar ve çoklu karşılaştırma sonuçları Çizelge 1'de izlenmektedir.

Çizelge 1. Farklı bitki türlerine ait bitki boyu, yeşil ve kuru madde verimleri

\begin{tabular}{lccc}
\multicolumn{1}{c}{ Bitki Türleri } & Bitki Boyu (cm) & Yeşil Ot Verimi (kg/da) & Kuru Madde Verimi (kg/da) \\
\hline Buğday & $96,7 \mathbf{c}$ & $4116,7 \mathbf{~ b}$ & $1272,3 \mathbf{~ b}$ \\
Arpa & $109,7 \mathbf{~ b}$ & $3666,7 \mathbf{~ b c}$ & $2228,2 \mathbf{~ a}$ \\
Tritikale & $139,0 \mathbf{~ a ~}$ & $3625,0 \mathbf{~ b c}$ & $1301,1 \mathbf{b}$ \\
Yulaf & $120,0 \mathbf{~ b}$ & $3083,3 \mathbf{c}$ & $1166,6 \mathbf{~ b}$ \\
Kolza & $135,0 \mathbf{a}$ & $4875,0 \mathbf{a}$ & $2471,4 \mathbf{~ a}$ \\
\hline Ortalama & 120,1 & 3873,3 & 1687,9 \\
\hline
\end{tabular}

Not: Aynı harfle gösterilen ortalamalar arasında fark yoktur.

Bitki türleri arasında bitki boyu yönünden önemli farkl1lıklar gözlenmiştir. En uzun bitki boyları 139,0 cm ile tritikale ve 135,00 cm ile kolzada belirlenmiştir. En kısa bitki boyu 96,7 cm ile buğdayda tespit edilmiştir.

Yeşil ot verimi açısından türler arasında önemli farklılıklar çıkmış, en yüksek yeşil ot verimi 4875,0 kg/da ile kolzada, en düşük yeşil ot verimi ise $3083,3 \mathrm{~kg} / \mathrm{da}$ ile yulafta belirlenmiştir.

Yeşil ot veriminde olduğu gibi kuru madde verimi yönünden de türler arasında önemli farklılıklar ortaya çıkmıştır. En yüksek kuru madde verimi kolza $(2471,4 \mathrm{~kg} / \mathrm{da})$ ve arpadan $(2228,2$ $\mathrm{kg} / \mathrm{da}$ ) en düşük kuru madde verimleri ise $1166,6,1272,3$ ve $1301,1 \mathrm{~kg} / \mathrm{da}$ ile sirasıyla yulaf, buğday ve tritikaleden elde edilmiştir.

Yapılan benzer bir çalışmada ortalama bitki boyunun arpada $95,0 \mathrm{~cm}$, buğdayda $94,5 \mathrm{~cm}$, çavdarda 90,3 cm, tritikalede $124,9 \mathrm{~cm}$ ve yulafta ise 140,3 olduğu kaydedilmiştir (Geren, 2014). 
Verimlerin genel olarak türüne, hasat edildiği döneme ve çevre şartlarına bağlı olarak değişmektedir (De Ruiter ve ark., 2002; De Ruiter ve Hanson, 2004). Bu yüzden Geren (2004)'in de belirttiği gibi kışlık tahıllarda ortalama kuru madde verimi 740,0-1009,3 kg/da arasında değişmiştir.

\section{Silajda ham protein oranı}

Ham protein içerikleri yönünden tritikale ve yulaf silajlarında katkı maddeleri ve dozları arasında önemli farklılıklar gözlenirken, buğday ve arpa silajlarında ise katkı maddeleri ve dozları arasında istatistiki olarak önemli bir farklılık tespit edilmemiştir (Çizelge 2). Türler içerisinde en yüksek ham protein oranı $\% 15,31$ ile arpa silajında belirlenirken, bunu $\% 14,35$ ile buğday ve $\% 13,80$ ile tritikale silajları izlemiştir. En düşük ham protein oranı ise \%12,42 ile yulaf silajında tespit edilmiştir.

Genel ortalamalara göre katkı maddelerinin silaj ham protein içeriklerine etkileri istatistiki olarak önemli olmuştur. En yüksek ham protein oranı \%14,66 ile \%10 arpa kırması, \%14,65 ile \%15 arpa kırması katkılarında, en düşük ham protein içeriğine ise $\% 12,88$ ile kontrolde belirlenmiştir.

Çizelge 2. Silajda ham protein oranlarına (\%) ait ortalamalar ve oluşan gruplar

\begin{tabular}{lccccc} 
Katkılar ve Dozları & Buğday & Arpa & Tritikale & Yulaf & Ortalama \\
\hline Arpa Kırmas1 \% 5 & 14,11 & 15,64 & $13,56 \mathbf{~ a b}$ & $11,76 \mathbf{a b}$ & $13,77 \mathbf{A B C}$ \\
Arpa Kırmas1 \% 10 & 14,44 & 15,03 & $15,03 \mathbf{a b}$ & $14,12 \mathbf{a}$ & $14,66 \mathbf{A}$ \\
Arpa Kırmas1 \% 15 & 14,17 & 14,99 & $15,40 \mathbf{a}$ & $14,04 \mathbf{a}$ & $14,65 \mathbf{A}$ \\
Bakteri 2,5 ppm & 14,49 & 16,03 & $13,37 \mathbf{~ a b}$ & $11,52 \mathbf{b}$ & $13,85 \mathbf{A B C}$ \\
Bakteri 5,0 ppm & 15,03 & 14,46 & $12,56 \mathbf{b}$ & $11,95 \mathbf{a b}$ & $13,50 \mathbf{B C}$ \\
Bakteri 7,5 ppm & 14,83 & 16,08 & $14,06 \mathbf{a b}$ & $12,96 \mathbf{a b}$ & $14,48 \mathbf{A B}$ \\
Kontrol & 13,34 & 14,92 & $12,66 \mathbf{b}$ & $10,59 \mathbf{b}$ & $12,88 \mathbf{C}$ \\
\hline Ortalama & $14,35 \mathbf{~ B}$ & $15,31 \mathbf{A}$ & $13,80 \mathbf{~ B}$ & $12,42 \mathbf{C}$ & - \\
\hline
\end{tabular}

Tritikale ve yulaf silajlarında katk1 maddelerinin ham protein oranlarına etkileri önemli bulunmuştur. Tritikalede en yüksek ham protein oranı $\% 15,40$ ile $\% 15$ arpa kırması en düşük ham protein oranı \%12,56 ve \%12,66 ile 5,0 ppm bakteri aşılaması ve kontrol uygulamalarında kaydedilmiştir. Yulaf silajlarında da benzer sonuçlar elde edilmiştir.

Denemede kullanılan türlere ait silajların ham protein oranlarının farklı çıkması genetik farklılıklarından kaynaklanmıştır. Katkı uygulamasının özellikle arpa kırmasının kontrole göre silaj ham protein oranını artırması arpadan ileri gelmiştir. Nitekim arpa silajının ham protein oranının diğer türlere göre daha yüksek çıkması bu görüşü desteklemektedir (Salantur, 2003). Benzer çalışmada toplamda 23 baklagil ve buğdaygil bitkisine uygulanan katk1 maddelerinin silaj ham protein oranını artırdı ğ 1 belirlenmiştir (Dumlu, 2007).

\section{Silajda ham selüloz oranı}

Katkılar ve dozları hemen bütün türlerde silajların ham selüloz oranlarına önemli etkilerde bulunmuştur. Anılan karakter yönünden tür x doz interaksiyonu da önemli çıkmıştır. Katkılar ve dozlarından elde edilen ham selüloz oranları hemen bütün türlerde kontrole göre önemli derecede daha düşük çıkmıştır. Ancak yulaf ve tritikalenin ham selüloz içerikleri diğerlerinden daha yüksek bulunmuştur (Çizelge 3).

Ham selüloz oranı yönünden bitki türlerine göre ortaya çıkan fark bitkilerin genetik özelliklerinden ileri gelmektedir.

Uygulanan katkı maddeleri silajın ham selüloz oranı kontrola göre $\% 8,7$ oranında azaltmıştır. Arpa kırması silajın ham selüloz oranını düșürmesi, arpa tanelerinin lif oranının düșük ve sindiriminin yüksek olmasından kaynaklanmaktadır (Kılıç ve Gül, 2007). Yapılan bir araştırmada, şeker pancarı yapraklarından yapılan silajlara uygulanan arpa kırmasının silajın hücre duvarı maddelerini (selüloz, hemiselüloz ve lignin) düşürdüğü saptanmıştır (Can ve ark., 2003). Diğer bir çalışmada ise 23 baklagil ve buğdaygil türlerinden oluşan bitkilerden elde edilen silajlara ilave edilen arpa kırmasının silajın hücre çeperi maddelerinin (NDF, $\mathrm{ADF}$ ve $\mathrm{ADL}$ ) oranlarını düşürdüğü saptanmıştır (Kılıç ve Gül, 2007).

Bakteri uygulaması silajın ham selüloz içeriğini kontrole göre önemli oranda düşürmüştür. Uygulanan laktik asit bakterileri silajın hücre duvarını enzimatik etki ile parçalayarak NDF, ADF, ADL, hemiselüloz ve selüloz içeriklerini düşürmekle beraber, kuru ve organik madde ile ADF ve NDF'nin sindirilme derecelerini artırmaktadır (Filya, 2002). Yapılan çalışmalarda da, bakteri 
uygulamasının besin madde parçalanabilirliği ve sindirilebilirliği üzerine olumlu etkiler yaptığı ortaya çıkmıştır (Chen ve ark., 1994; Nadeau ve ark., 2000; Filya, 2002).

Çizelge 3. Silajda ham selüloz oranlarına (\%) ait ortalamalar ve oluşan gruplar

\begin{tabular}{|c|c|c|c|c|c|}
\hline Katkılar ve Dozları & Buğday & Arpa & Tritikale & Yulaf & Ortalama \\
\hline Arpa Kırmas1 \% 5 & $35,02 \mathbf{a}$ & $32,80 \mathbf{a b}$ & $36,89 \mathbf{a}$ & $35,76 \mathbf{b c}$ & $35,12 \mathbf{B}$ \\
\hline Arpa Kırmas1 \% 10 & $34,11 \mathbf{a b}$ & $34,04 \mathbf{a b}$ & $36,67 \mathbf{a}$ & $36,09 \mathbf{b}$ & $35,23 \mathbf{B}$ \\
\hline Arpa Kırmas1 \% 15 & 33,45 abc & $35,03 \mathbf{a}$ & $32,36 \mathbf{a b}$ & $32,57 \mathbf{c}$ & $33,35 \mathbf{C}$ \\
\hline Bakteri 2,5 ppm & $30,80 \mathbf{b c}$ & $33,72 \mathbf{a b}$ & $37,02 \mathbf{a}$ & $38,56 \mathbf{a b}$ & $35,03 \mathbf{B}$ \\
\hline Bakteri 5,0 ppm & 30,85 bc & $32,91 \mathbf{a b}$ & $37,54 \mathbf{a}$ & $39,42 \mathbf{a}$ & 35,18 B \\
\hline Bakteri 7,5 ppm & $29,96 \mathbf{c}$ & $31,53 \mathbf{b}$ & $36,25 \mathbf{a b}$ & $37,50 \mathbf{a b}$ & $33,81 \mathbf{B C}$ \\
\hline Kontrol & $36,94 \mathbf{a}$ & $34,57 \mathbf{a}$ & $38,43 \mathbf{a}$ & $40,61 \mathbf{a}$ & $37,64 \mathbf{A}$ \\
\hline Ortalama & $33,02 \mathbf{B}$ & $33,52 \mathbf{B}$ & $36,45 \mathbf{A}$ & $37,22 \mathbf{A}$ & \\
\hline
\end{tabular}

\section{Silajda Renk}

Silajda renk, bitkinin hasat edildiğindeki rengi koruyup korumadığına göre belirlenen bir değerlendirme kriteridir. Olumlu fermantasyonda genellikle bitkiler yeşil rengini muhafaza etmektedir. Renk ortalamaları yönünden arpa ve tritikale silajlarında katkılar ve dozları arasında önemli farklılıklar ortaya çıkmıştır. Türler arasında buğday ve arpada daha yüksek renk değerleri gözlenmiştir. En düşük renk ortalaması ise 1,10 ile tritikale silajında tespit edilmiştir. Diğer yandan arpa kırmasının \%10 ve \%15 oranlarında uygulandığı silajlarda daha iyi renk değerleri kaydedilmiştir (Çizelge 4).

Çizelge 4. Silajda renk ortalamaları ve oluşan gruplar*

\begin{tabular}{lccccc}
\hline Katkılar ve Dozları & Buğday & Arpa & Tritikale & Yulaf & Ortalama \\
\hline Arpa Kırmas1 \% 5 & 1,67 & $1,33 \mathbf{~ b c}$ & $1,00 \mathbf{b}$ & 1,33 & $1,33 \mathbf{A B}$ \\
Arpa Kırmas1 \% 10 & 1,67 & $1,67 \mathbf{~ a b}$ & $1,00 \mathbf{~ b}$ & 1,67 & $1,50 \mathbf{A}$ \\
Arpa Kırmas1 \% 15 & 1,67 & $1,33 \mathbf{~ b c}$ & $1,67 \mathbf{a}$ & 1,33 & $1,50 \mathbf{A}$ \\
Bakteri 2,5 ppm & 1,00 & $2,00 \mathbf{a}$ & $1,00 \mathbf{b}$ & 1,33 & $1,33 \mathbf{A B}$ \\
Bakteri $5,0 \mathrm{ppm}$ & 1,00 & $2,00 \mathbf{a}$ & $1,00 \mathbf{b}$ & 1,00 & $1,25 \mathbf{A B}$ \\
Bakteri 7,5 ppm & 1,67 & $1,33 \mathbf{~ b c}$ & $1,00 \mathbf{b}$ & 1,33 & $1,33 \mathbf{A B}$ \\
Kontrol & 1,00 & $1,00 \mathbf{c}$ & $1,00 \mathbf{b}$ & 1,33 & $1,08 \mathbf{B}$ \\
\hline Ortalama & $1,38 \mathbf{A}$ & $1,524 \mathbf{A}$ & $1,10 \mathbf{B}$ & $1,33 \mathbf{A B}$ & \\
\hline
\end{tabular}

* 0 kötü, 1 orta, 2 iyi olarak değerlendirilmiştir.

\section{Silajda Koku}

Yulaf dışında diğer tahıl türlerinden yapılan silajlarda katkı maddelerinin koku üzerine etkileri önemli bulunmuştur. Bitki gruplarına göre en yüksek koku değeri 9,33 ile arpa silajında görülürken, en düşük koku değeri 4,05 ile tritikale silajında tespit edilmiştir (Çizelge 5).

Çizelge 5. Silajda koku ortalamaları ve olușan gruplar*

\begin{tabular}{|c|c|c|c|c|c|}
\hline Katkılar ve Dozları & Buğday & Arpa & Tritikale & Yulaf & Ortalama \\
\hline Arpa Kırmas1 \% 5 & $7,00 \mathbf{a b}$ & $8,67 \mathbf{a}$ & $4,33 \mathbf{b c}$ & 6,67 & $6,67 \mathbf{A B}$ \\
\hline Arpa Kırmas1 \% 10 & $7,00 \mathbf{a b}$ & $9,00 \mathbf{a}$ & 3,67 bcd & 7,00 & $6,67 \mathbf{A B}$ \\
\hline Arpa Kırmas1 \% 15 & $7,67 \mathbf{a}$ & $10,00 \mathbf{a}$ & $6,33 \mathbf{a}$ & 6,67 & $7,67 \mathbf{A}$ \\
\hline Bakteri 2.5 ppm & $3,67 \mathbf{c}$ & $10,67 \mathbf{a}$ & $4,00 \mathbf{b c}$ & 5,33 & 5,92 B \\
\hline Bakteri $5.0 \mathrm{ppm}$ & 5,33 abc & $10,00 \mathbf{a}$ & $4,67 \mathbf{b}$ & 4,67 & 6,17 B \\
\hline Bakteri 7.5 ppm & $6,00 \mathbf{a b c}$ & $10,67 \mathbf{a}$ & 3,00 cd & 6,00 & 6,42 B \\
\hline Kontrol & $5,00 \mathbf{b c}$ & $6,33 \mathbf{b}$ & $2,33 \mathbf{d}$ & 4,33 & $4,50 \mathrm{C}$ \\
\hline Ortalama & 5,95 B & $9,33 \mathbf{A}$ & $4,05 \mathrm{C}$ & 5,81 B & \\
\hline
\end{tabular}

* 0 kötü tereyağı asidi kokusu var, 14 hoş, aromatik koku var.

Katkı maddelerinin silajda koku üzerine etkileri istatistiki olarak önemlilik göstermiştir. Buna göre ortalama en yüksek koku değeri 7,67 ile \%15 arpa kırması uygulamalarında gözlenirken, en 
düşük koku ortalamasına 4,50 ile kontrol grubu silaj örneklerinde tespit edilmiştir. Katkı maddelerinin bitki silajlarının koku ortalamalarına etkilerinde buğdayda en yüksek 7,67 ile \%15 arpa kırmas1 uygulamalarında, en düşük koku değeri ise 3,67 ile 2,5 ppm bakteri uygulamalarında görülmüştür. Arpa silajlarında en yüksek koku değeri 10,67 ile bakteri uygulamalarında, en düşük koku değeri ise 6,33 ile kontrol örneklerinde tespit edilmiştir. Tritikale de en yüksek koku değeri 6,33 ile \%15 arpa kırması ilavesinde, en düşük renk değeri 2,33 ile katkısız silaj örneklerinde kaydedilmişstir.

\section{Silajda Strüktür}

Strüktür değerleri yönünden katkı ve katkı dozları arasında buğday, arpa ve tritikale silajlarında önemli farklılıklar tespit edilmiştir. Diğer yandan arpa silajlarının yeşile yakın özelliklerini muhafaza ederken, tritikale silajlarının önemli derecede bozulduğu dikkati çekmiştir. En yüksek strüktür değeri 2,17 ile \% 15 arpa kırması silaj örneklerinde belirlenirken, bunu 2,08 ile \% 10 arpa kırması eklenen silaj izlemiştir. En düşük strüktür değeri ise 1,42 ile katkısız silaj uygulamalarında gözlenmiştir. Katkı maddeleri silaj strüktür değerlerini olumlu etkilemiştir (Çizelge 6).

Çizelge 6. Silajda strüktür ortalamaları ve oluşan gruplar*

\begin{tabular}{|c|c|c|c|c|c|}
\hline Katkılar ve Dozları & Buğday & Arpa & Tritikale & Yulaf & Ortalama \\
\hline Arpa Kırmas1 \% 5 & $1,67 \mathbf{b c}$ & $2,33 \mathbf{b}$ & $1,33 \mathbf{a b}$ & 1,67 & $1,75 \mathbf{A B}$ \\
\hline Arpa Kırmas $1 \% 10$ & $2,33 \mathbf{a b}$ & $2,33 \mathbf{b}$ & $1,33 \mathbf{a b}$ & 2,33 & $2,08 \mathrm{~A}$ \\
\hline Arpa Kırmas1 \% 15 & $2,67 \mathbf{a}$ & $2,33 \mathbf{b}$ & $2,00 \mathbf{a}$ & 1,67 & $2,17 \mathbf{A}$ \\
\hline Bakteri 2.5 ppm & $1,00 \mathbf{c}$ & $3,67 \mathbf{a}$ & $1,33 \mathbf{a b}$ & 1,67 & $1,92 \mathbf{A B}$ \\
\hline Bakteri 5.0 ppm & $2,00 \mathbf{a b}$ & $3,00 \mathbf{a b}$ & $1,67 \mathbf{a b}$ & 1,00 & $1,92 \mathbf{A B}$ \\
\hline Bakteri 7.5 ppm & $2,33 \mathbf{a b}$ & $2,33 \mathbf{b}$ & $1,00 \mathbf{b}$ & 2,00 & $1,92 \mathbf{A B}$ \\
\hline Kontrol & $1,67 \mathbf{b c}$ & $1,33 \mathbf{c}$ & $1,00 \mathbf{b}$ & 1,67 & 1,42 B \\
\hline Ortalama & $1,95 \mathbf{B}$ & $2,48 \mathbf{A}$ & $1,38 \mathbf{C}$ & $1,71 \mathbf{B C}$ & \\
\hline
\end{tabular}

* 0 bozulmuş, 4 orijinalini koruyor.

Silajın fiziksel özellikleri üzerine türlere göre kısmen farklılık göstermekle birlikte uygulanan katkı maddelerinin etkileri genel olarak olumlu bulunmuştur. Silajda duyusal özelliklerin iyi olmasının temel nedeni en uygun fermantasyon ortamının sağlanmasıdır (Geren, 2001). Nitekim yapılan çalışmalarda da benzer sonuçlar elde edilmiştir (Geren, 2001; Polat ve ark., 2005; Kılıç ve Gül, 2007; Tobia ve ark., 2008).

\section{Sonuç ve Öneriler}

Çalı̧̧mada, kışlık tahılların silaj üretiminde başarılı bir şekilde kullanılabileceği, yeşil ot verimi yönünden buğdayın, kuru madde verimi yönünden arpanın öne çıtığı tespit edilmiștir.

Silajların ham protein içeriğini, uygulanan katkı maddeleri, özellikle arpa kırması ilavesi önemli derecede arttırmıştır.

Silaja arpa kırması ve bakteri solüsyonu ilavesi, fermantasyonu artırmış, hücre duvarı bileşenlerinin daha fazla yıkılmasını sağlamıștır. Bu yüzden katkı maddeleri ilavesi ham selüloz oranı önemli derecede azalmıştır.

Renk, koku ve strüktür özellikleri arpa kırması ilavesinden olumlu etkilenmiştir. Duyusal özelliklere göre arpa silajı daha iyi puanlar almıştır.

Sonuç olarak, kışlık tahıllardan silaj yapımı esnasında karbonhidrat kaynağı olarak \% 10-15 oranında arpa kırması ilavesinin yararlı olacağı tespit edilmiştir.

\section{Kaynaklar}

Can, A., Denek, N., Yazgan, K., 2003. Şeker pancarı yaprağına değiş̧ik katkı maddeleri ilavesinin silaj kalitesi ile in vitro kuru madde sindirilebilirlik düzeylerine etkisi. YYÜ Veterinerlik Fakültesi Dergisi, 14 (2): 26-29.

Chen, J., Stokes, M.R., Wallace, C.R., 1994. Effects of enzyme - inoculant systems on preservation and nutritive value of hay crop and corn silages. J. Dairy Sci., 77, 501-512.

De Ruiter, J.M., Hanson, R., 2004. Whole crop cereal silage- production and use in dairy, beef, sheep and deer farming. Christchurch, NZ: NZ Institute for Crop and Food Research Ltd.

De Ruiter, J.M., Hanson, R., Hay, A.S., Armstrong, K.W., Harrison-Kirk, R.D., 2002. Whole-crop cereals for grazing and silage: balancing quality and quantity. Proceedings of the New Zealand Grassland Association., 64: 181-189. 
ÇOMÜ Zir. Fak. Derg. (COMU J. Agric. Fac.)

2018: 6 (Özel Say1): 249-254

ISSN: 2147-8384 / e-ISSN: 2564-6826

Dumlu, Z., 2007. Erzurum Şartlarında Bazı Çok Yıllık Baklagil ve Buğdaygil Yem bitkilerinin Silajlık Kullanımları Üzerine Bir Araștırma. Atatürk Üniversitesi Fen Bil. Enst., Basılmamış Yüksek Lisans Tezi, Erzurum.

Filya, İ., 2002. Laktik asit bakteri ve laktik asit bakteri+enzim karışımı silaj inokulantlarının mısır silajı üzerine etkileri. Turk. J. Vet. Anim. Sci., 26: 679-687.

Geren, H., 2001. Bornova koşullarında ikinci ürün olarak yetiştirilen farklı mısır çeşitlerinde ekim zamanlarının silaj özelliklerine etkisi. Ege Üniv. Zir. Fak. Derg., 38 (2-3): 47-54, 2001.

Geren, H., 2014. Dry matter yield and silage quality of some winter cereals harvested at different stages under Mediterranean climate conditions. Turkish Journal of Field Crops., 19 (2): 197-202.

Kılıç, H., Gül, İ., 2007. Hasat Zamanının Diyarbakır Şartlarında İkinci Ürün Olarak Yetiştirilen Mısır

Çeşitlerinde Verim ve Bazı Tarımsal Karakterler ile Silaj Kalitesine Etkileri Üzerine Bir Araştırma,

Harran Universitesi Ziraat Fakültesi Dergisi, 11(3/4): 43-52

Nadeau, E.M.G., Buxton, D.R., Russell, J.R., Allison, M.J., Young, J.W., 2000. Enzyme, bacterial inoculant, and formic acid effects on silage composition of orchardgrass and alfalfa. Journal of Dairy Sci., 83 (7): 1487-1502.

Polat, C., Koç, F., Özgüven, M.L., 2005. Mısır silajında laktik asit bakteri ve laktik asit bakteri+enzim karışımı inokulantların fermantasyon ve toklularda ham besin maddelerinin sindirilme dereceleri üzerine etkileri. Tekirdağ Univ. Zir. Fak. Derg., 2 (1): 13-22.

Salantur, A., 2003. Erzurum ve Pasinler Ovalarındaki Buğdaygil Bitkilerinin Yetiştiği Topraklardan İzole Edilen Asimbiyotik Bakteri Şuşlarının Buğday ve Arpada Gelişme ve Verim Üzerine Etkileri. Atatürk Üniversitesi Fen Bilimleri Enstitüsü Tarla Bitkileri Anabilim Dalı, Doktora Tezi, Erzurum.

Tobia, C., Villalobos, E., Rojas, A., Soto, H., Moore, K.J., 2008. Nutritional value of soybean (Glycine max L. Merr.) silage fermented with molasses and inoculated with Lactobacillus brevis. Livestock Res. for Rural Development., 20 (7): 106. 